\title{
Development of Molecular Marker and Variability Characterization of Aspergillus flavus Isolates of Chilies (Capsicum frutescens L.) through RAPD-PCR and Estimation of Aflatoxin $B_{1}$ by Indirect Competitive ELISA in India
}

\author{
Virendra Kumar1, Ajay Kumar², Shailesh Kumar Kannojia ${ }^{3}$, Rana Pratap Singh ${ }^{4}$ \\ ${ }^{1}$ Regional Pesticides Testing Laboratory, Ministry of Agriculture, Department of Agriculture \& Cooperation, \\ Directorate of Plant Protection Quarantine and Storage, Kanpur, India \\ ${ }^{2}$ Department of Botany, Kashi Naresh Govt. P. G. College, Bhadohi, India \\ ${ }^{3}$ Department of Biotechnology, V.B.S. Purvanchal University, Jaunpur, India \\ ${ }^{4}$ Udai Pratap Autonomous College, Varanasi, India \\ Email: drkumarvirendra@gmail.com, ranaptsingh@yahoo.co.in
}

Received 29 October 2014; revised 30 November 2014; accepted 17 December 2014

Copyright (C) 2014 by authors and OALib.

This work is licensed under the Creative Commons Attribution International License (CC BY).

http://creativecommons.org/licenses/by/4.0/

(c) (i) Open Access

\begin{abstract}
Aflatoxin is the most potent toxic substances, these are the group of closely related mycotoxins produced by fungus i.e. Aspergillus flavus. Twenty seven isolates of $A$. flavus designated as $A f-1$, $A f-2, A f-4, A f-5, A f-7, A f-9, A f-11, A f-12, A f-13, A f-15, A f-25, A f-28, A f-31, A f-33, A f-34, A f-35, A f-36$, $A f-37, A f-39, A f-40, A f-46, A f-47, A f-54, A f-55, A f-58, A f-59$ and $A f-60$ were collected from different agro climatic conditions from chilies (Capsicum frutescence) samples. Random amplified polymorphic DNA-PCR analysis was used to investigate genetic variation among these isolates. Molecular variability study was done to find out the best annealing temperature and sixty primers were screened to select for maximum polymorphism of DNA. The best annealing temperature was recorded $34^{\circ} \mathrm{C}$ for the pathogen and most efficient amplification and polymorphism of DNA was found with random primer 5'-CAGGCGCACA-3'. This primer sequence had also been identified as a typical A. flavus isolate which produced sclerotia in APA medium. In another set of experiments, occurrence of aflatoxin $B_{1}$ in chilies from India was determined by using indirect competitive ELISA in work undertaken in Indian Institute of Vegetable Research, Varanasi, India. Among twenty chilies samples, the toxin concentration ranged from $15.3-782.3 \mu \mathrm{g} / \mathrm{kg}$ and all chilies samples were positive for aflatoxin $B_{1}$. Out of twenty seven $A$. flavus isolates, seven samples were found to be toxigenic. UAS Dharwad (B) chilies sample was found most toxigenic because it was found to be producing maximum yellow fluorescence light on exposure of UV (365 $\mathrm{nm}$ ) light.
\end{abstract}

How to cite this paper: Kumar, V., et al. (2014) Development of Molecular Marker and Variability Characterization of Aspergillus flavus Isolates of Chilies (Capsicum frutescens L.) through RAPD-PCR and Estimation of Aflatoxin $B_{1}$ by Indirect Competitive ELISA in India. Open Access Library Journal, 1: e1161. http://dx.doi.org/10.4236/oalib.1101161 


\title{
Keywords
}

\author{
Chilies, RAPD-PCR, Aspergillus flavus, Aflatoxin $\mathrm{B}_{1}$, ELISA, Toxigenic
}

Subject Areas: Molecular Biology, Mycology, Plant Science, Toxicology

\section{Introduction}

Chilies are one of the most important crops of India. Aflatoxins are heat stable compounds and normally do not easily degrade during common food or feed processing. Residual effect of this toxin is high and it does not degrade at high temperature up to $280^{\circ} \mathrm{C}$. Many researchers have studied the pathway of aflatoxin biosynthesis and they have devised strategies to intervene its production so that its contamination can be reduced [1]. PCR-based technique, involving the random amplification of polymorphic DNA (RAPD) has been used for assessing genomic variability among a wide range of culture collection strains of Aspergillus and related species. The utility of DNA markers as RAPD-DNA employ it as well established sample molecular marker tool for detecting genetic variability for many phytopathogenic fungi. RAPD polymorphism results from a nucleotide base change, an insertion or deletion that alters the primer binding sites. This product can be polymorphic and may be used as genetic markers for extensive genetic variation analysis. An advantage of this technique is that the primers are universal and they can be used for genomic analysis of a wide variety of species. The research project of analyzing genetic diversity by RAPD-PCR is very useful to detect similarities and differences in different fungal species. Random amplified polymorphic DNA more or less randomly distributed in the whole genome [2].

A. flavus is known as contaminant of different agricultural commodities such as peanut, chilies, rice, maize, barley, sorghum and milk. India is the major exporter of the chilies crop and the level of other exporting countries were China (24\%), Spain (17\%), Mexico (8\%), Pakistan (7.2\%), Morocco (7\%) and Turkey (4.5\%). Chilies are subject to various pest and disease constraints to optimal production. The contamination of the crops with aflatoxin from the growth of A. flavus and/or Aspergillus nominus is one of the most serious problems [3]. Aflatoxins are the most dangerous mycotoxin and are extremely carcinogenic [4]. The toxicity of aflatoxin is due to "Bisfuronococematin" compound which may causes liver cancer in human beings, chicken and cattles. Pulmonary aspergillosis, mycotic endocarditis and mycotic meningitis are common human health problems caused by Aspergillus sp. [5]-[7]. The growth of aflatoxin producing Aspergillus species depends on a substrate and environmental factors, such as water activity, temperature, $\mathrm{pH}$ and microbial competition. A. flavus and A. paraciticus are considered as xerophilic since they can grow at low water activities (aw $0.75-0.8$ ) [8]. The common toxigenic species of Aspergillus are A. flavus, A. ochraceous, A. parasiticus, A. coctatus, A. pseudotumarin, A. bombycis and $A$. nominus, [9] and [10]. Aflatoxin from chili may be threat to the health of population and a constraint on development in India. The Aflatoxin $B_{1}$ is very much harmful to the humans; it is highly carcinogenic in nature [10]. In India, it is also a great problem and creates economic loss. Among all storage fungi contamination of A. flavus lacks host specialization is much deadly and cause many acute and chronic effects on human being [11], animals and plant [12] because aflatoxin production is more stable in nature than in culture. The EU has a stipulated maximum residual level (MRL) of aflatoxin for species at $5 \mu \mathrm{g} / \mathrm{kg}$ for $\mathrm{AFB}_{1}$ and $10 \mu \mathrm{g} / \mathrm{kg}$ for total aflatoxins $\left(B_{1}+B_{2}+G_{1}+G_{2}\right.$ ) (Commission regulation 2002). However India has statutory standards or regulation for this commodity [13].

The aim of the present study was to characterize twenty seven different isolates of $A$. flavus at molecular level and also study the concentrations of aflatoxin in various chilies samples which highlighting the aflatoxin $B_{1}$ along with identification of toxigenic strains among different isolates of $A$. flavus under the fluorescent UV light. Limited research on various aspects of Aflatoxin and Aspergillus on chilies fruit encouraged us to investigate into this problem.

\section{Materials and Methods}

The analytical grade chemicals were used in all experiments of this manuscript.

A. flavus cultures isolated and purified from infected dry chilies samples collected from different agro-climatic zones of India and purified by the hyphal tip method. A. flavus isolates were also confirmed by the mor- 
phological study. They were stored at $4^{\circ} \mathrm{C}$ on PDA slants ( Peeled potato slices $200 \mathrm{~g}$, dextrose $20 \mathrm{~g}$, agar-agar $20 \mathrm{~g}$, distilled water $1000 \mathrm{ml}$ ) for further study.

\subsection{Molecular Characterization}

All isolates are being maintained at the Indian Institute of Vegetable Research, Varanasi (U.P.) India.

\subsection{Fungal DNA Extraction}

Fungi were grown in $50 \mathrm{ml}$ of potato dextrose broth medium for 10 days at $25^{\circ} \mathrm{C} \pm 1{ }^{\circ} \mathrm{C}$ temperature in BOD. DNA was extracted by pure mycelial culture of $A$. flavus according to CTAB protocol [14].

\subsection{PCR Amplification}

PCR was carried out in a final volume of $25 \mu \mathrm{l}$, containing $10 \mathrm{mM}$ of oligonucletide primer $(1 \mu \mathrm{l}) 20 \mathrm{mM}$ of each of the four deoxynucleotide triphosphates $(0.75 \mu \mathrm{l}) 25 \mathrm{mM} \mathrm{MgCl}_{2}(1.0 \mu \mathrm{l}), 0.35 \mu \mathrm{l}$ of Taq DNA polyme-

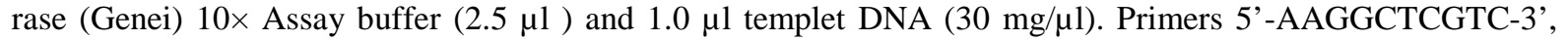
5'-CACGGCGAGT-3', 5'-TTCGAGCCAG-3', 5'-CAGGCGCACA-3' and 5'-AAAGCTGCGG-3' were chosen after preliminary screening of sixty primers. The reaction mixture was overlaid with $10 \mu \mathrm{l}$ of mineral oil and the tube was microfuged at 13,000 g for $10 \mathrm{~s}$. Amplification was carried out in a gradient thermal cycler (Eppendorf) with initial denaturation of $94^{\circ} \mathrm{C}$ for $4.0 \mathrm{~min}$ and 40 cycles of $94^{\circ} \mathrm{C}$ for $1.0 \mathrm{~min}, 34^{\circ} \mathrm{C}$ for $1.0 \mathrm{~min}$ and $72^{\circ} \mathrm{C}$ for $5 \mathrm{~min}$.

\subsection{Electrophoresis}

Twenty $\mu$ l of PCR product were mixed with $6 \mu \mathrm{l}$ of gel loading buffer $(0.25 \%$ bromophenol blue, $0.25 \%$ xylene cynol and 30\% glycerol were dissolved in $1 \times$ TAE buffer) and subjected to electrophoresis at $65 \mathrm{~V}$ for $3 \mathrm{~h}$ in $1.2 \%$ agarose gel, prepared in $1 \times$ TAE buffer ( $40 \mathrm{mM}$ Tris acetate $1 \mathrm{mM}$ EDTA, $\mathrm{pH}$ 8.0). Ethidium bromide was added to the agarose gel at $6 \mu \mathrm{l} / 100 \mathrm{ml}$ for staining. A ladder (Lambda DNA/Eco RI + Hind III) was used as a size standard. DNA was visualized by trans-illuminator with u.v. light and photographed. For each fungal isolates, individual RAPD markers were scored for their presence (value $=1$ ) or absence (value $=0$ ). RAPD scores were used for similarity analysis using Jaccord coeffiecient and clustering using UPGMA (Unweighted Pair Group Method of Arithmetic average). It was constructed using numerical taxonomy and multivariate analysis system software [15].

\section{Chemical and Regents for Indirect Competitive ELISA}

Twenty chilies samples (Figure 3 from $S_{1}$ to $S_{20}$ ) including powder and intact samples were collected randomly from market, shops and chilies growing area between May and June from different agro-climatic zones of India. Samples were stored at $-4^{\circ} \mathrm{C}$ in sealed polythene bags until analysis and it was tested for aflatoxin $\mathrm{B}_{1}$ by indirect competitive ELISA. All the material was obtained from Fluka, Sigma (USA) for the preparation of reagents.

\subsection{Reagents}

The following reagents were used to perform indirect competitive ELISA:

$\mathrm{AFB}_{1}$-BSA conjugates (supplied from ICRISAT, Hyderabad), Phosphate buffer saline (PBS) contains, $\mathrm{Na}_{2} \mathrm{HPO}_{4}$ (2.38 g), $\mathrm{KH}_{2} \mathrm{PO}_{4}(0.4 \mathrm{~g}), \mathrm{KCl}(0.4 \mathrm{~g}), \mathrm{NaCl}$ (16.0 g), Carbonate buffer (coating buffer) contains, $\mathrm{Na}_{2} \mathrm{CO}_{3}$ (1.59 g), $\mathrm{NaHCO}_{3}$ (2.93 g), Phosphate buffered saline with Tween-20 (PBS-T) contains $0.5 \mathrm{ml}$ of Tween-20, Albumin bovine serum (BSA) contains $200 \mathrm{mg}$ BSA dissolved in $100 \mathrm{ml}$ PBS-T and Antiserum contains $1.5 \mu \mathrm{l}$ of antiserum.

\subsection{Preparation of Healthy Chilies Extract for Standard Solution of ELISA}

Red healthy chilies pods were harvested from field and dried at $80^{\circ} \mathrm{C}$ for three days in hot air oven. After that, few chilies samples were again dried in sun light and were incubated in BOD at $28^{\circ} \mathrm{C}$ by maintaining humidity and covered with transparent plastic sheet in a plastic tray to confirm A. flavus free chili. After 48 hours the observations were taken. Those chilies samples which found to be free from A. flavus or any other contaminants 
that was selected for methanol extraction and used as healthy chilies extract for aflatoxin negative control.

\subsection{Positive Control}

$10 \%$ healthy chilies extract were prepared in BSA, now $2.5 \mu \mathrm{AFB}_{1}$ added in $1 \mathrm{ml}$ of healthy chilies extract. Therefore this solution would be $25 \mathrm{ng} / 100 \mu \mathrm{l}$ toxin concentration for standard. It was used as positive control.

\subsection{Dilution of Enzyme Labeled IgG}

Added $5 \mu \mathrm{l}$ original anti-rabbit IgG in $20 \mathrm{ml}$ of BSA in a tube and vortex it for proper mixing.

\subsection{Substrate Preparation}

One of tablet (20 mg) of p-nitro phenyl phosphatase dissolved in $40 \mathrm{ml}$ of $10 \%$ diethanolamine.

\subsection{Methanol Extraction from Chilies Samples}

Twenty chilies samples were collected from different states of the country (Figure 3) and these chilies samples were previously dried in oven and ground to fine powder with the help of mixer. $20 \mathrm{~g}$ of each chilies powder was ground in $100 \mathrm{ml}$ of $70 \%$ ethanol with help of pestle and mortar. This ethanol was already supplemented with $0.5 \% \mathrm{KCl}$. It was filtered with Whatman filter paper No. 1 and the filtrate collected in plastic bottles separately and stored at $-20^{\circ} \mathrm{C}$ for further analysis of aflatoxin through ELISA.

\subsection{Standard Protocol for Indirect Competitive ELISA}

1) Step 1. $2.5 \mu \mathrm{l} \mathrm{AFB}_{1}$ BSA were taken in $25 \mathrm{ml}$ of carbonate buffer (coating buffer) in a dry sterilized oak ridge tube to make a final concentration i.e. $100 \mathrm{ng} / \mathrm{ml}$.

2) Step 2. Coating: above mixture was mixed properly by vortex and dispensed $150 \mu \mathrm{l}$ in each well of ELISA plate with the help of multichannel pipette and was incubated at $37^{\circ} \mathrm{C}$ for 2 hours.

3) Step 3. After incubation, it was washed three times with PBS-T upto three minutes for each washing with help of wash bottles.

4) Step 4. Blocking-After washing, $150 \mu \mathrm{l}$ of $0.2 \%$ BSA (prepared in PBS-Tween) added in each well of ELISA plate and incubated at $37^{\circ} \mathrm{C}$ for $1 \mathrm{hr}$.

5) Step 5. Washed these ELISA plate, three times with PBS-T as in Step 3. After washing positive and negative control samples of Aflatoxin along with test samples were loaded and antiserum dilution was done in different wells of ELISA plate.

6) First two rows of ELISA plate were chosen for standard preparation with two replications and 10 test samples were loaded from third row of ELISA plate starting from well No. 2 to 11, Well No. 2 contains $100 \mathrm{ng} / \mu \mathrm{l}$ aflatoxin concentration and serial dilution was done from well No. 2 - 10 and Well No. 11 is completely free of toxin.

7) Step 6. Now total volume in all wells was adjusted $100 \mu \mathrm{l}$ including all positive and negative control samples. Now $50 \mu \mathrm{l}$ antiserum were loaded in each well of test sample and incubated at $37^{\circ} \mathrm{C}$ for one hour.

8) Step 7. After incubation, this ELISA plate was washed three times with PBS-T and loaded $150 \mu \mathrm{l}$ of prepared IgG in each wells and again incubated at $37^{\circ} \mathrm{C}$ for 1 hour. After that, this plate was again washed with PBS-T.

9) Step 8. Now $150 \mu \mathrm{l}$ of freshly prepared substrate solution loaded in each wells and kept it for 30 - 45 minute at room temperature in dark condition for the color development.

10) Step 9. Finally O.D. was taken at $405 \mathrm{~nm}$ with ELISA reader. A standard graph was plotted for log concentrations of standard solution and O.D. to obtain the concentration of test sample and then calculated the reading for concentration of $\mathrm{AFB}_{1} \mu \mathrm{g} / \mathrm{kg}$ in test sample by following formula:

$$
\mathrm{AFB}_{1}(\mu \mathrm{g} / \mathrm{kg})=(\mathrm{A} \times \mathrm{B} \times \mathrm{E}) / \mathrm{G}
$$

where, $\mathrm{A}=\mathrm{AFB}_{1}$ concentration in diluted or concentrated sample extract $(\mathrm{ng} / \mathrm{ml})$;

$\mathrm{B}=$ Time dilution with buffer;

$\mathrm{E}=$ Extraction solvent volume used in $\mathrm{ml}$;

$\mathrm{G}=$ Sample weight in $\mathrm{g}$. 


\subsection{Isolation and Purification of A. flavus from Dry Red Chilies Samples}

In another set of experiments the toxigenicity identification of different isolates of A. flavus carried out. For these purpose twenty seven chilies samples were screened, using blotter paper technique for fungal flora (particularly A. flavus). Chilies fruits were selected and surface sterilized by serially dipping in antibiotic solution (Streptocyclin@ 200 - 300 ppm) for 1 minutes, then 1\% solution of sodium hypochloride (NaOCl) for 1 - 2 minutes and finally washed with distilled water for three times to remove residue of $\mathrm{NaOCl}$ from chilies fruits. These sterilized fruits were kept in moist chamber, using sterilized Petri plates, filter paper disc and sterile distilled water and incubated at $25^{\circ} \mathrm{C}$. It was observed after five days of incubation, the particularly for the emergence of A. flavus. The hyphal tip of suspected to A. flavus on incubated chilies fruits were taken by sterilized needle and also inoculated on PDA Petri plates and incubated in BOD for 5 days at $28^{\circ} \mathrm{C}$. After 5 days of incubation the spores from the margin of apparently distinct colonies was sub cultured on fresh PDA Petri plates. The pure culture of the A. flavus taken from hyphal tip (periphery of the colony) was transferred into new fresh slants. In this way the culture of different isolates were purified and maintained for sub-culturing in-subsequent experiment. These isolates are designated as Af-1, Af-2, Af-4, Af-5, Af-7, Af-9, Af-11, Af-12, Af-13, Af-15, Af-25, Af-28, Af-31, Af-33, Af-34, Af-35, Af-36, Af-37, Af-39, Af-40, Af-46, Af-47, Af-54, Af-55, Af-58, Af-59 and Af-60. For this toxigenicity identification experiment was laid out. The following specific medium was prepared to find out the toxigenic strain of $A$. flavus reported by [16] i.e. known as aflatoxin producing agar medium (APA medium). This specific medium contains $\left(\mathrm{NH}_{4}\right) \mathrm{H}_{2} \mathrm{PO}_{4}-10 \mathrm{~g}, \mathrm{~K}_{2} \mathrm{HPO}_{4}-1 \mathrm{~g}, \mathrm{MgSO}_{4} \cdot 7 \mathrm{H}_{2} \mathrm{O}-0.5 \mathrm{~g}, \mathrm{KCl}-0.5 \mathrm{~g}$, $\mathrm{FeSO}_{4} \cdot 7 \mathrm{H}_{2} \mathrm{O}-0.01 \mathrm{~g}$, Sucrose $-30 \mathrm{~g}, \mathrm{HgCl}_{2}(135.5 \mathrm{mg} / \mathrm{l})-5 \times 10^{-4}$ mole, $\mathrm{ZnSO}_{4}-0.25 \mathrm{~g}$, Sodium extract$0.01 \mathrm{~g}$, Agar—20 g, Chilies extract—200 ml and Distilled water maintained up to $1000 \mathrm{ml}$.

\subsection{Preparation of Chilies Extract}

$100 \mathrm{~g}$ dry intact chilies were soaked in $200 \mathrm{ml}$ of distilled water and boiled for 20 minute at $100^{\circ} \mathrm{C}$ then filter with blotter paper and the filtrate were used as chilies extract for APA medium preparation as mentioned above. This medium was autoclaved at $121^{\circ} \mathrm{C}$ for 15 minutes and poured in $100 \mathrm{~mm}$ of Petri plates, $5 \mathrm{~mm}$ culture disc of $A$. flavus were inoculated on these medium and incubated at $28^{\circ} \mathrm{C} \pm 1{ }^{\circ} \mathrm{C}$ temperature in BOD for 8 days. Plates were examined under UV light $(365 \mathrm{~nm})$ illumination on $8^{\text {th }}$ days of incubation for the presence and absence of greenish yellow fluorescence in the agar surrounding the colony.

\section{Results and Discussion}

Molecular studies were carried out to find variability in isolates of $A$. flavus by RAPD-PCR. Five random primers (5'-AAGGCTCGTC-3', 5'-CACGGCGAGT-3', 5'-TTCGAGCCAG-3', 5'-CAGGCGCACA-3' and 5'AAAGCTGCGG-3') were selected for preliminary screening of 60 random primers because of their reproducible results of polymorphism between individuals. These primers were used to survey the genetic diversity within a collection of 27 isolates of $A$. flavus. Of twenty seven isolates (i.e. Af-1, Af-2, Af-4, Af-5, Af-7, Af-9, Af-11, Af-12, Af-13, Af-15, Af-25, Af-28, Af-31, Af-33, Af-34, Af-35, Af-36, Af-37, Af-39, Af-40, Af-46, Af-47, Af-54, $A f-55, A f-58, A f-59$, and $A f-60)$ collected from different agro climatic region were screened with sixty random primers. The best annealing temperature, PCR conditions and best primer sequence for A. flavus standardized. The ideal PCR condition was 42 cycles of denaturation at $95^{\circ} \mathrm{C}$ for 3.0 minute, annealing at $34^{\circ} \mathrm{C}$ for 40 second was recorded as optimum annealing temperature (Figure 1) and used for further and extension for 1.20 second at $70^{\circ} \mathrm{C}$. The most efficient amplification and polymorphism of DNA were found by 5'-CAGGCGCACA-3'. The primer clearly amplified DNA of Af-5, Af-7, Af-9, Af-13, Af-47, Af-54, Af-58, and Af-59 with prominent DNA band of same size. Sclerotia were also observed in isolates of $A f-5, A f-7, A f-9$ and $A f-13$ and maximum polymorphism observed in these isolates. The close relation among $A f-54, A f-58$ and $A f-59$ isolate with $80 \%$ similarity coefficient was recorded. The isolates $A f-5, A f-7$ and $A f-9$ may be having the least variability at molecular level. The primer sequence may be helpful in identifying the typical A. flavus isolates producing sclerotia in culture media and further study of RAPD. The isolates, Af-33, Af-34, Af-35, Af-36, Af-37, Af-39, Af-40, and Af-46 are unable to produce any bands. So these isolates are clearly confirmed the non-toxigenic isolates of $A$. flavus (Table 2). In present finding, RAPD analysis shows a close relation among Af-7 and Af-9 isolates with $80 \%$ similarity coefficient. It is clear that even similarity of isolates is observed at molecular level. RAPD analysis of A. flavus isolates indicated that chilies isolates from India are hyper variable with distinct variation Figure 2 \& Figure 3. 


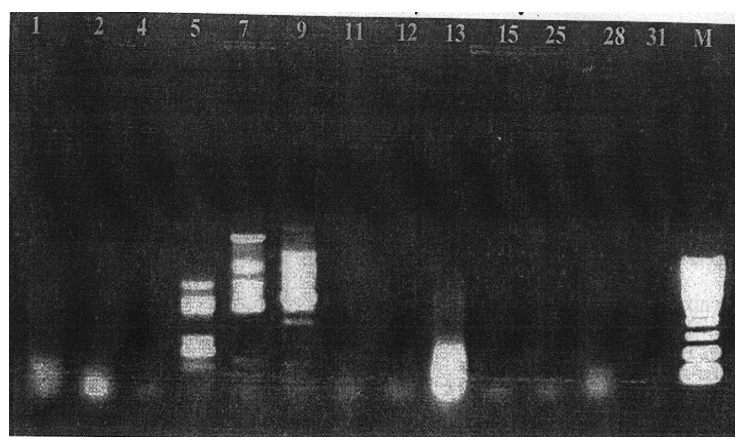

Figure 1. DNA profile of 13 isolates of $A$. flavus by Primer 5'-CAGGCGCACA-3', isolates Af-1, $A f-2, A f-4, A f-5, A f-7, A f-9, A f-11, A f-12, A f-13, A f-15, A f-25, A f-28$ and $A f-31 . M=$ molecular marker (Lambda DNA/Eco RI + Hind III).

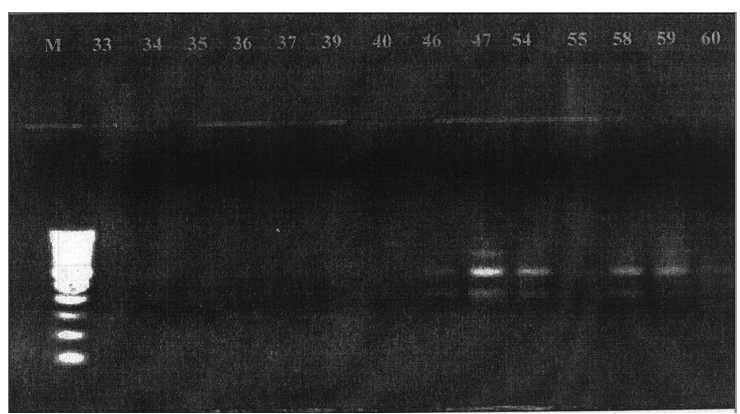

Figure 2. DNA profile of 14 isolates of A. flavus by Primer 5'-CAGGCGCACA-3', isolates Af-33, Af-34, Af-35, Af-36, Af-37, Af-39, Af-40, Af-46, Af-47, Af-54, Af-55, Af-58, Af-59 and Af-60. $\mathrm{M}=$ molecular marker (Lambda DNA/Eco RI + Hind III).

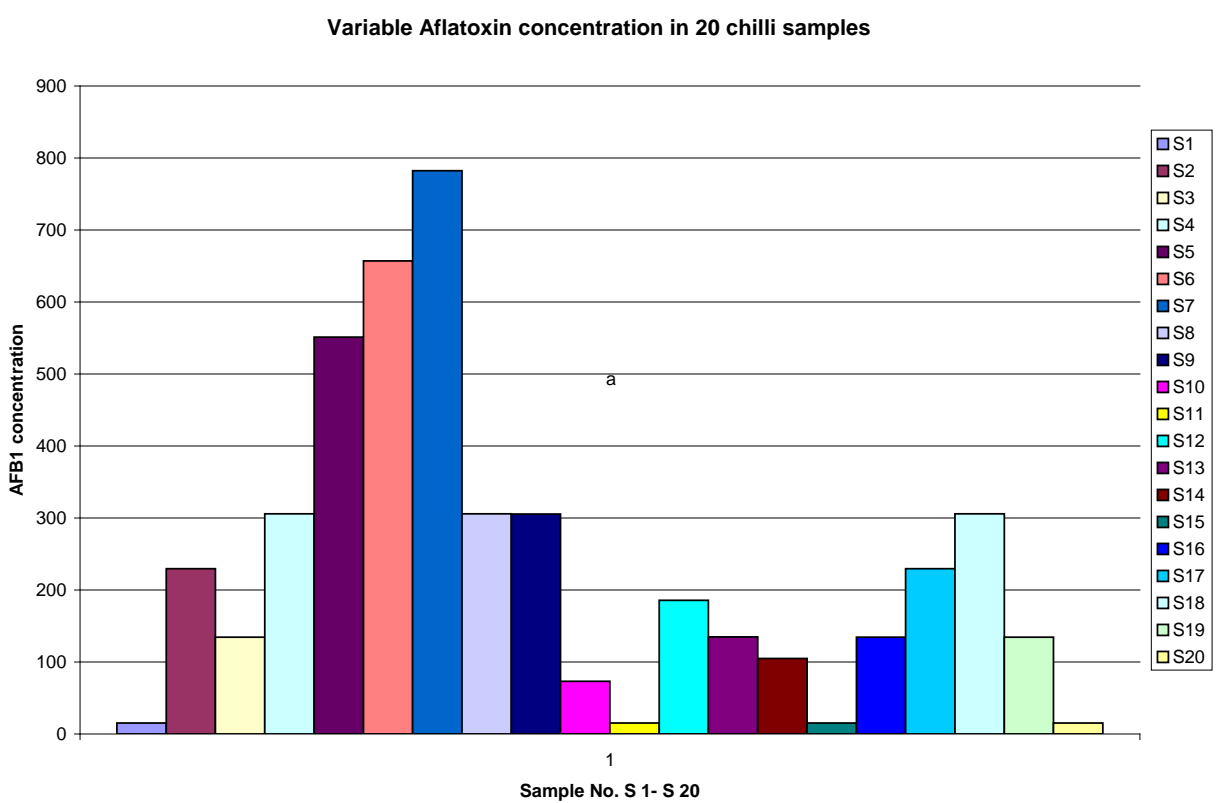

Where $\mathrm{S}=$ Chili Sample. $\mathrm{S}_{1}=$ Junagarh (Gujrat) A, $\mathrm{S}_{2}=$ Chunar (Mirzapur, U.P.), $\mathrm{S}_{3}=$ Sangroor (Panjab), $\mathrm{S}_{4}=\mathrm{Ko}-$ vilpatti, (T.N.) (B), $S_{5}=$ Warangal, (A.P.) (A), $S_{6}=$ Warangal, (A.P.) (B), $S_{7}=$ USA Dharwad (Karnataka) (B), $S_{8}=$ Bakonam, (T.N.), $S_{9}=$ Junagarh, (Gujrat) (B), $S_{10}=$ Kanpur, (U.P.), $S_{11}=$ Sundarpur, Varanasi (U.P.), $S_{12}=$ Guntur, (A.P), $S_{13}=$ Lawad, (U.P.), $S_{14}=$ Faridabad (Haryana), $S_{15}=$ Goladeenanath, Varanasi (U.P.), $S_{16}=$ Kovilpatti, (T.N.) (A), $\mathrm{S}_{17}=$ Varanasi, (U.P.), $\mathrm{S}_{18}=$ BCA Sabour, (Bihar), $\mathrm{S}_{19}=$ Dharwad (Karnataka), $\mathrm{S}_{20}=$ Adalpura, (Mirzapur)

Figure 3. Aflatoxin concentration of twenty chilies samples detected through indirect competitive ELISA. 
[17] studied the molecular variability among seventeen isolates of A. flavus by using PCR-RFLP of its region or rDNA. They were found that the amplification of a product of approximately $600 \mathrm{bp}$. Digestion of PCR products with the restriction enzymes ECO R I, Hae III and Taq I produced fragments of different sizes. Cluster analysis using the unweighted pair group method with arithmetic average (UPGMA). Clearly separate the isolates into five groups confirming the genetic diversity among the A. flavus isolates from maize. The amount of AFB1 produced by the isolates of A. flavus ranged from 1.9 to $206.6 \mathrm{ng} / \mathrm{ml}$. one isolates produced the highest amount of AFB1 i.e. $206.6 \mathrm{ng} / \mathrm{ml}$. While [18] observed the genetic variability in A. flavus isolates from two Brazilian agro-ecosystems. He found 36 isolates as aflatoxigenic among 48 isolates. One hundred forty one DNA bands were generated with 11 random amplified polymorphic DNA (RAPD) and analysed via UPGMA.

\subsection{Isolation and Purification of Organisms from Chilies Samples}

Total twenty seven isolates of $A$. flavus were selected from 100 chili samples from blotter paper technique. The twenty seven isolates were maintained in PDA slant and stored at low temperature $\left(4^{\circ} \mathrm{C}\right)$ for further study (Table 1).

Table 1. List of A. flavus isolates obtained from different chilli samples of the country.

\begin{tabular}{|c|c|c|c|}
\hline S. No. & Designation & Location/District & State \\
\hline 1 & $A f-1$ & Junagarh (A) & Gujrat \\
\hline 2 & $A f-2$ & Junagrah (B) & Gujrat \\
\hline 3 & $A f-4$ & Gola Dinanath, Varanasi & U.P. \\
\hline 4 & $A f-5$ & Sundarpur, Varanasi & U.P. \\
\hline 5 & $A f-7$ & Chunar, Mirzapur & U.P. \\
\hline 6 & $A f-9$ & Adalapura, Mirzapur & U.P. \\
\hline 7 & $A f-11$ & Dharwad & Karnataka \\
\hline 8 & $A f-12$ & Kovilpatti (A) & Tamilnadu \\
\hline 9 & $A f-13$ & Kovilpatti (B) & Tamilnadu \\
\hline 10 & $A f-15$ & Bakonam & Tamilanadu \\
\hline 11 & $A f-25$ & UAS Dharwad & Karnataka \\
\hline 12 & $A f-28$ & Faridabad & Haryana \\
\hline 13 & $A f-31$ & Kanpur & U.P. \\
\hline 14 & $A f-33$ & Lawad & Meerut \\
\hline 15 & $A f-34$ & IIVR-Varanasi & U.P. \\
\hline 16 & Af-35 & Warangal & A.P. \\
\hline 17 & Af-36 & Khamam & A.P. \\
\hline 18 & $A f-37$ & Guntur & A.P. \\
\hline 19 & $A f-39$ & Varanasi & U.P. \\
\hline 20 & $A f-40$ & UAS Dharwad (A) & Karnataka \\
\hline 21 & Af-46 & Sangroor & Punjab \\
\hline 22 & $A f-47$ & Rohatak & Haryana \\
\hline 23 & $A f-54$ & BCA Sabour & Bihar \\
\hline 24 & $A f-55$ & Chandigarh & Haryana \\
\hline 25 & $A f-58$ & Panchkula & Haryana \\
\hline 26 & $A f-59$ & Warangal (B) & A.P. \\
\hline 27 & $A f-60$ & Rajapur & Haryana \\
\hline
\end{tabular}




\subsection{Estimation of Aflatoxin through Indirect Competitive ELISA from Various Chilies Samples}

The concentrations of Aflatoxin $B_{1}$ in various chilies samples are presented in Figure 3. The maximum toxin were recorded in UAS Dharwad sample followed by Warangal, A.P. (B), Warangal, A.P. (A), i.e. $782.3 \mu \mathrm{g} / \mathrm{kg}$, $657.05 \mu \mathrm{g} / \mathrm{kg}$ and $551.3 \mu \mathrm{g} / \mathrm{kg}$ respectively while minimum toxin $(15.3 \mu \mathrm{g} / \mathrm{kg})$ were recorded in 3 districts of our country i.e. Junagarh, Varanasi (Sundarpur), Varanasi (Gola Deenanath) and Mirzapur (Adalpura). 305.7 $\mu \mathrm{g} / \mathrm{kg}$ toxin was recorded in Kovilpatti (Tamilnadu), Bakonam (Tamil Nadu), Junagarh, (Gujarat), BCA Sabaour, (Bihar).

\subsection{Identification of Toxigenic A. flavus Isolates}

Among 27 isolates of A. flavus, seven isolates were observed as toxigenic and rests of the isolates were found to be non-toxigenic. In toxigenic isolate $A f-25$, produced much fluorescent light after exposing of UV-rays ( $365 \mathrm{~nm}$ ) followed by $A f-2, A f-15, A f-35, A f-54$ and $A f-59$ and the isolate $A f-7$ and $A f-13$ produced least toxin. Beside this eighteen isolates of $A$. flavus Af-1, Af-4, Af-5, Af-9, Af-11, Af-12, Af-28, Af-31, Af-33, Af-34, Af-36, Af-37, Af-40, $A f-46, A f-47, A f-55, A f-58$ and $A f-60$, observed as non-toxigenic isolates (Table 2).

Table 2. List of toxigenic and non toxigenic isolates of $A$. flavus.

\begin{tabular}{|c|c|c|c|c|}
\hline S. No. & Organisms No. & Location/District & State & $\begin{array}{l}\text { Intensity of yellow fluorescence in APA } \\
\text { medium on UV exposure (365 nm) }\end{array}$ \\
\hline 1 & $A f-1$ & Junagarh (A) & Gujrat & - \\
\hline 2 & Af-2 (IT) & Junagrah (B) & Gujrat & ++ \\
\hline 3 & Af-4 & Gola Dinanath, Varanasi & U.P. & - \\
\hline 4 & $A f-5$ & Sundarpur, Varanasi & U.P. & - \\
\hline 5 & $A f-7$ & Chunar, Mirzapur & U.P. & + \\
\hline 6 & $A f-9$ & Adalapura, Mirzapur & U.P. & - \\
\hline 7 & $A f-11$ & Dharwad & Karnataka & - \\
\hline 8 & $A f-12$ & Kovilpatti (A) & Tamilnadu & - \\
\hline 9 & Af-13 & Kovilpatti (B) & Tamilnadu & + \\
\hline 10 & Af-15 & Bakonam & Tamilanadu & ++ \\
\hline 11 & $A f-25$ & UAS Dharwad (B) & Karnataka & ++++ \\
\hline 12 & $A f-28$ & Faridabad & Haryana & - \\
\hline 13 & $A f-31$ & Kanpur & U.P. & - \\
\hline 14 & $A f-33$ & Lawad & Meerut & - \\
\hline 15 & $A f-34$ & IIVR-Varanasi & U.P. & - \\
\hline 16 & Af-35 & Warangal (A) & A.P. & - \\
\hline 17 & $A f-36$ & Khamam & A.P. & - \\
\hline 18 & $A f-37$ & Guntur & A.P. & - \\
\hline 19 & $A f-39$ & Varanasi & U.P. & - \\
\hline 20 & $A f-40$ & UAS Dharwad (A) & Karnataka & - \\
\hline 21 & Af- 46 & Sangroor & Punjab & - \\
\hline 22 & $A f-47$ & Rohatak & Haryana & - \\
\hline 23 & $A f-54$ & BCA Sabour & Bihar & ++ \\
\hline 24 & $A f-55$ & Chandigarh & Haryana & - \\
\hline 25 & $A f-58$ & Panchkula & Haryana & - \\
\hline 26 & $A f-59$ & Warangal (B) & A.P. & ++ \\
\hline 27 & $A f-60$ & Rajapur & Haryana & - \\
\hline
\end{tabular}

$+++++=$ Maximum yellow fluorescent light recorded. $++=$ Medium yellow fluorescent light recorded. $+=$ Low yellow fluorescent light recorded. = No yellow fluorescent light recorded. 
Regarding estimation of aflatoxin, few workers [19] and [20] did some work on Aflatoxin detection. [19] reported that aflatoxin concentration in toxigenic strain of A. flavus ranges from 10.47 - $482.58 \mu \mathrm{g} / \mathrm{kg}$ obtained in peanut sample, while in chilies sample, it is slightly higher than the peanut. Although [21] reported natural occurrence of aflatoxin $B_{1}$ in chilies pods through HPLC. They had reported maximum aflatoxin $B_{1}$ in chilies pods as $5.5 \mu \mathrm{g} / \mathrm{kg}$. In our chilies samples, the toxin concentration was ranging from $15.3-782.3 \mu \mathrm{g} / \mathrm{kg}$. [19] found that $88 \%$ of A. flavus were toxigenic and aflatoxin producing strain produced maximum $1652.2 \mu \mathrm{g} / \mathrm{kg}$ and minimum $6.6-10.2 \mu \mathrm{g} / \mathrm{kg}$ in chili fruit samples, our findings of toxin concentration are in the range as reported by [19].

[22] tested aflatoxin $B_{1}$ in vitro by indirect competitive enzymes-linked immunosorbant assay in different agricultural commodities like maize, groudnut, chiles cotton and tree nuts. The amount of $\mathrm{AFB}_{1}$ produced by toxigenic isolates of A. flavus ranged from 6.6 to $108.1 \mathrm{ng} / \mathrm{ml}$. The genetic variability among various isolates was RAPD analysis. DNA fragments of between 0.15 and $3.0 \mathrm{~kb}$ were obtained using 13 random primers. Theses group was indicating that no relationship exist between RAPD profile and the production of aflatoxin by a $A$. flavus [23]. Examined that the genetic relationship between toxigenic and non-toxigenic isolates using RAPD. Twenty four RAPD amplifications using a combination of 17 primers discriminated between 20 isolates of $A$. flavus. No association was seen between RAPD genotype and the ability to produce toxin and multiple losses of toxigenicity in A. flavus have occurred. While [24] studied the mycological profile of the retail wheat flour, the most common genera were Aspergillus. The twenty nine strains of $A$. flavus were screened for their ability to produce aflatoxins. The flour strains produced $\mathrm{AFB}_{1}$ and aflatoxin $\mathrm{B}_{2}$. RAPD technique could not differentiate between toxigenic and nontoxigenic strains of $A$. flavus AF regulatory gene was detected in three flour samples and in seven A. flavus isolates. [25] were analysed to by using amplified fragment length polymorphic (AFLPs) to compare 82 isolates of Aspergillus section Flavi. AFLP analysis indicates that no genotypical differences can be established between aflatoxin and nonaflatoxigenic producers. [26] determined the aflatoxin $\mathrm{B}_{1}$ by using HPLC the main concentration in powdered chiles, $32.20 \mu \mathrm{g} / \mathrm{kg}$ was recorded. The concentrations ranged from 0.00 to $89.56 \mu \mathrm{g} / \mathrm{kg}$ for powdered chilies. The limit of detection and quantification were $0.05 \mu \mathrm{g} / \mathrm{kg}$ and 0.53 $\mu \mathrm{g} / \mathrm{kg}$, respectively. The concentrations were recorded high in general and greater than the statuary limit set by the European Union.

Many of the workers such as [27]-[35] have done a lot of work for the identification of toxigenic and non toxigenic strain of A. flavus. [33] reported that the strain of $A$. flvaus which produced small sclerotia is less toxigenic while those $A$. flavus isolates which produce large sclerotia are highly toxigenic. Different Aflatoxin producing strain of $A$. flavus determined by fluorescence, in aflatoxin producing agar (APA) medium under U.V. (365 nm) light. Total 27 isolates of A. flavus from chili of different provinces of the country, these isolates of $A$. flavus were grown on APA medium. Slight modification was done in these composition of medium as suggested by [35] in our experiments and data were taken after 8 days of inoculation by exposing directly UV light (365 $\mathrm{nm}$ ) on these A. flavus grown Petri plates. The toxigenic strain of A. flavus plates was giving light yellow fluorescent color on the medium \& non toxigenic strain have no effect on exposure of UV light because they were not reflecting fluorescent from the APA medium, the result are summarized in Table 2.

In our experiment one isolate i.e. Af-9 from Uttar Pradesh which produced small sclerotia that was found to be lesser toxigenic under the UV light treatment. This isolate is also have much polymorphic bands as compared to RAPD analysis so it is completely different from other isolates at molecular level because it is single isolates which produce small sclerotia in our experiment. Therefore this is the conformation of results as reported by [33]. Besides, these [30] suggested that the microflora and the toxigenicity varied with sample and geographical location, similar findings had been observed in our experiment (Table 2) developed one new culture media for rapid identification of aflatoxin producing Aspergillus strain. He had found that Aflatoxin producing strain of $A$. flavus flourise blue green fluorescent area surrounding the colony when observed under long wave length (365 $\mathrm{nm}$ ) UV light after 3 day of incubation at $20^{\circ} \mathrm{C}$. But in our experiment, greenish yellow fluorescent area was observed in $A f-2, A f-7, A f-13, A f-15, A f-25, A f-35, A f-39, A f-54$ and $A f-59$ on exposing UV light (365 nm) after 8 days of incubation at $28^{\circ} \mathrm{C}$. This variation may be due to the different media composition because the media which were taken in our experiment was reported by [35] i.e. APA medium.

Aflatoxocoses in human was reported in many countries like India, China, Thailand and several African countries. Apart from that, due to capacity of aflatoxin to cross the placentation barrier can cause genetic defects at fetal stage itself [35], studies relating to aflatoxin exposures of human in India are not much studied. However, the problem is present and may break loose at any time in near future, as incidence of aflatoxin contamination in food and feeds is very common. Therefore, prevention and management of aflatoxin in different agricultural 
commodities are very necessary.

The present study provides new data on molecular characterization of A. flavus in India. The identified primer sequence may be helpful in identifying the typical $A$. flavus isolates producing sclerotia in culture media. The contamination with aflatoxin $\mathrm{B}_{1}$ of Indian chilies was found to be higher than that recommended by the EU in some cases. This is unacceptable, if the country is to compete in modern open market place, and moreover has negative health implications for the population. More careful production of chilies products in India is required. Chili production in India may be heavily constrained by aflatoxin contamination simply removing A. flavus may be insufficient for control. This technique has been used in the determination of aflatoxins in food will continue to be developed and improved.

\section{Acknowledgements}

Authors are very much thankful to SV Reddy (ICRISAT Hyderabad) who trained the corresponding author about ELISA and Dr. P.K. Pandey, Ex-Head, Division of Crop Protection, Indian Institute of Vegetable Research (IIVR), Varanasi, India, for their constant encouragement and providing the resources to carry out the research work.

\section{References}

[1] Bhatnagar, D.K., Khlich, C. and Cleveland, T.E. (1993) Biochemical Characterization of an Aflatoxin B2 Producing Mutant of Aspergillus flavus. FASEB Journal, 7, A1234.

[2] Saba, I. and Rabiya, N. (2012) Molecular Characterization of Seven Different Species of Aspergillus through Random Amplified Polymorphic DNA (RAPD) and Enzymes Analysis. Journal of Microbiological Research, 2, 47-50. http://dx.doi.org/10.5923/j.microbiology.20120203.01

[3] Paterson, R.R.M. (2007) Aflatoxin Contamination in Chili Samples from Pakistan. Food Contamination, 18, 817-820. http://dx.doi.org/10.1016/j.foodcont.2006.04.005

[4] Paterson, R.R.M. and Lima, N. (2010) Toxicology of Mycotoxins. In: Lunch, A., Ed., Molecular Clinical and Environmental Toxicology, Vol. 2, Springer, Basel, 31-63. http://dx.doi.org/10.1007/978-3-7643-8338-1_2

[5] Henrici, A.T. (1940) Characteristics of Fungal Diseases. Journal of Biotechnology, 39, 113-138.

[6] Kirschstein, R.L. and Sidransky, H. (1965) Mycotic Endocarditis of Tricuspid Vave Due to Aspergillus flavus. Archive of Phtopathology and Plant Protection, 62, 103-106.

[7] Ziskind, J., Pizzalato and Philp, B.E. (1958) Aspergillos in Brain. American Journal of Clinical Pathology, 29, 554559.

[8] Ito, Y., Peterson, S.W., Wiclow, D.T. and Goto, T. (2001) Aspergillus pseudotamari, a New Aflatoxin-Producing Species in Aspergillus Section Flavi. Mycological Research, 105, 233-239. http://dx.doi.org/10.1017/S0953756200003385

[9] Goto, T. (2005) Aflatoxigenic and Non Aflatoxigenic Species in Aspergillus Section Flavi. Journal of the Faculty of Agriculture Shinshu University, 41, 1-6.

[10] Deiner, U.L., Cole, R.J., Sanders, T.H., Payne, G.A. and Lee, K. (1987) Epidemiology of Alfatoxin Formation of by Aspergillus flavus. Annual Review of Phytopathology, 25, 249-270. http://dx.doi.org/10.1146/annurev.py.25.090187.001341

[11] Leger, R.J., Screen, S.E. and Shams-Pirzadeh, B. (1999) Lack of Host Specilization in Aspergillus flavus. Applied and Environmental Microbiology, 66, 320-324.

[12] Raisbeck, M.F., Rottinghaus, G.E. and Kendall, J.D. (1991) Effects of Naturally Occuring Mycotoxins on Ruminants. In: Smith, J.E. and Henderson, R.S., Eds., Mycotoxins and Animal Foods, CRC Press, Boca Raton, 647-677.

[13] Reddy, S.V., Mayi, D.K., Reddy, M.U., Thirumala-Devi, K. and Reddy, D.V.R. (2001) Aflatoxin B ${ }_{1}$ in Different Grades of Chillies (Capsicum annum L.) in India as Determined by Indirect Competitive ELISA. Food Additives \& Contaminants, 18, 553-558. http://dx.doi.org/10.1080/02652030119491

[14] Manicom, B.Q., Bar-Joseph, M., Rosner, A., Vigodsky-Hans, H. and Kotze, J.M. (1987) Potential Applications of Random DNA Probes, and Restriction Fragment Length Polymorphism in the Taxonomy of Fusaria. Phytopathology, 77, 669-672. http://dx.doi.org/10.1094/Phyto-77-669

[15] Weir, T.L., Huff, D.R., Christ, B.J. and Romaine, C.P. (1998) RAPD-PCR Analysis of Genetic Variations among Isolates of Alternaria solani and Alternaria alternata from Potato and Tomato. Mycologia, 90, 813-821. http://dx.doi.org/10.2307/3761323

[16] Hara, S., Fennell, D.I. and Hesseltine, C.W. (1974) Aflatoxin Producing Strain of Aspergillus flavus Detected by Fluo- 
rescence of Agar Medium under U.V. Light. Applied Microbiology, 27, 1118-1123.

[17] Mohankumar, M., Vijayamundeeswari, A., Karthikeyan, M., Mathiyazahagan, S., Paranidhavan, V. and Velzhahan, R. (2010) Analysis of Molecular Variability among Isolates of Aspergillus flavus by PCR-RFLP of the Its Regions of rDNA. Journal of Plant Protection Research, 50, 446-451.

[18] Midorikawa, G.E.O., Pinheiro, M.R.R., Vidigal, B.S., Arrunda, M.C., Costa, F.F., Pappas Jr., G.J., Ribeiro, S.G., Freire, F. and Miller, R.N.G. (2008) Characterization of Aspergillus flavus Strains from Brazilian Brazil Nuts and Cashew by RAPD and Ribosomal DNA Analysis. Society for Applied Microbiology, 11, 1472-1765.

[19] Ajithkumar, K. and Naik, M.K. (2006) Detection of Aflatoxin Producing A. flavus Isolates from Chili and Their Management by Post Harvest Treatment. Journal of Food Science and Technology, Mysore, 43, 200-204.

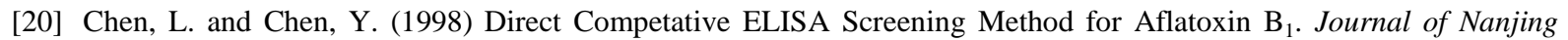
Agricultural University, 21, 62-65.

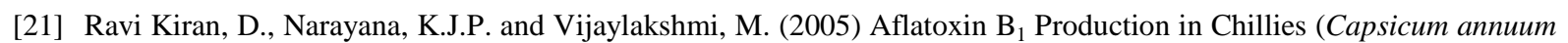
L.) Kept in Cold Storage. African Journal of Biotechnology, 4, 791-795.

[22] Shweta, S., Kanan, K., Madhawan, S., Adithya, R., Paranidharan, V. and Velazhahan, R. (2013) RAPD Analysis of Genetic Diversity among the Isolates of Aspergillus flavus from Different Host and Locations. Archives of Phytopathology and Plant Protection.

[23] Tran-Dinh, N., Pitt, J.I. and Carter, D.A. (1999) Molecular Genotype Analysis of Natural Toxigenic and Nontoxigenic Isolates of Aspergillus flavus and A. parasiticus. Mycological Research, 103, 1485-1490. http://dx.doi.org/10.1017/S0953756299008710

[24] Gashgari, R.M., Shebany, Y.M. and Ghabacoy, Y.A. (2010) Molecular Characterization of Mycobiota and Aflatoxin Contamination of Retail Wheat Flour from Jeddah Markets. Foodborne Pathogens and Disease, 7, 1047-1054. http://dx.doi.org/10.1089/fpd.2009.0506

[25] Barros, G.G., Chitta, M.L., Reynoso, M.M., Torres, A.M. and Chulze, S.N. (2007) Molecular Characterization of Aspergillus Section Flavi Isolates Collected from Peanut Field in Argentina Using AFLPs. Journal of Applied Microbiology, 103, 900-909. http://dx.doi.org/10.1111/j.1365-2672.2007.03312.x

[26] Iqbal, S.Z., Paterson, R.R.M., Bhatti, I.A., Asi, M.R., Sheikh, M.A. and Bhatti, H.N. (2010) Aflatoxin B B $_{1}$ Chilies from the Punjab Region, Pakistan. Mycotoxin Research, 26, 205-209. http://dx.doi.org/10.1007/s12550-010-0055-6

[27] Singh, I. and Singh, V.P. (2002) Comparative Studies on Growth Patterns and Metabolic Status of Aflatoxin, Producing and Non Producing Strains of Aspergillus flavus. Current Science, 82, 1425-1426.

[28] Wicklow, D.T. (1999) Influence of Aspergillus flavus Strain on Aflatoxin and Bright Greenish Yellow Fluorescence of Carn Kernels. Plant Disease, 83, 1146-1148. http://dx.doi.org/10.1094/PDIS.1999.83.12.1146

[29] Saito, M. and Machida, S. (1999) A Rapid Identification Method for Aflatoxin-Producing Strains of Aspergillus flavus and A. parasiticus by Ammonia Vapor. Mycoscience, 40, 205-208. http://dx.doi.org/10.1007/BF02464300

[30] Girdhari, P. and Reddy, S.M. (1999) Mycofflora in Relation to Mycotoxins Incidence in Red Pepper. Advances in Plant Science, 12, 85-88.

[31] Schearer, C.G., Wright, S., Krosch, J., Tatnell, A. and Kyei (1999) Effect of Temperature on Grown and Aflatoxin Production by Non-Toxigenic (Strain 4351) and Toxigenic (Strain 2754). Aspergillus flavus. ACIAR Food Legume, News Letter No. 29, 4-7.

[32] Abbas, H.K., Weaver, M.A., Zabitowicz, R.M., Horn, B.W. and Shier, W.T. (2005) Relationships between Aflatoxin Production and Sclerotia Formation among Isolates of Aspergillus Section Flavi from the Mississippi Delta. European Journal of Plant Pathology, 112, 283-287. http://dx.doi.org/10.1007/s10658-004-4888-8

[33] Shier, W.T., Lao, Y.B., Steele, T.W.J. and Abbas, H.K. (2005) Yellow Pigments Used in Rapid Identification of Aflatoxin Producing Aspergillus Strains Are Anthraquinones Associated with the Aflatoxin Biosynthesis Pathway. Bioorganic Chemistry, 33, 426-438. http://dx.doi.org/10.1016/j.bioorg.2005.09.002

[34] Fente, C.A., Ordaz, J.J., Vozquez, B.I., Frnaco, C.M. and Cepeda, A. (2001) New Additive for Culture Media for Rapid Idenitification of Aflatoxin-Producing Aspergillus Strains. Applied and Environmental Microbiology, 87, 4858-4862. http://dx.doi.org/10.1128/AEM.67.10.4858-4862.2001

[35] Maxwell, S.M., Apeagyei, F., De Vries, H.R., Mwanmut, D.D. and Hendrickse, R.G. (1998) Aflatoxin in Breast Milk, Neonatal Cord Blood and Sera of Pregnant Women. Toxicological Reviews, 8, 12-29. 